\title{
Profile of bictegravir/emtricitabine/tenofovir alafenamide fixed dose combination and its potential in the treatment of HIV-I infection: evidence to date
}

REVIEW

\author{
Lucas Hill' \\ Shawn R Smith' \\ Maile Young Karris ${ }^{2}$ \\ 'University of California San Diego \\ Skaggs School of Pharmacy and \\ Pharmaceutical Sciences, San Diego, \\ CA, USA; ${ }^{2}$ Department of Medicine, \\ University of California San Diego, \\ San Diego, CA, USA
}

This article was published in the following Dove Press journal: HIVIAIDS - Research and Palliative Care

\begin{abstract}
Modern pharmacologic management of people living with HIV involves the use of fixed dose combinations of antiretrovirals that are simple to take, well tolerated, and highly effective. Specific recent pharmacologic advancements include 1) the second-generation integrase strand transfer inhibitors (dolutegravir and bictegravir) that consistently show less side effects, high tolerability, minimal drug interactions, and rapid rates of HIV viral load decline and 2) tenofovir alafenamide, a prodrug of tenofovir that concentrates in lymphoid tissue and minimizes off target effects. Bictegravir/emtricitabine/tenofovir alafenamide or B/F/TAF is a recently approved fixed dose combination that incorporates these new advancements in the management of HIV. This review focuses on the data supporting the use of B/F/TAF, reviews clinically relevant findings, and highlights the unanswered questions that may limit its clinical utility.
\end{abstract} Keywords: Biktarvy, HIV care, review, integrase strand transfer inhibitor

\section{Introduction}

Advancements in antiretroviral therapy (ART) broadened the treatment options for people living with HIV (PLWH) who are both naïve to therapy and treatment experienced. Newer classes of medications provide high genetic barriers to resistance, excellent tolerability, and are often co-formulated into fixed dose combinations that simplify the dosing. Recently, the US Food and Drug Administration (FDA) added to the available options for many PLWH with the approval of bictegravir (BIC).

BIC is a novel integrase strand transfer inhibitor (INSTI) approved by the FDA in February 2018 for PLWH who are treatment naïve and for PLWH virologically suppressed on current ART for at least 3 months with no history of prior treatment failure or resistance to any component of the BIC single tablet regimen (STR). BIC has been shown to potently inhibit strand transfer activity at concentrations similar to that of elvitegravir (EV G) and dolutegravir (DTG) with its unique structure minimizing drug-drug interactions, increasing protein binding, and improving solubility. BIC has a favorable pharmacokinetic (PK) profile in that it can be dosed once daily and is not impacted by renal or hepatic impairment. Although BIC is a substrate of CYP3A4 and UGTI1A1, it does not require pharmacologic boosting resulting in minimal drug interactions. In vitro, BIC demonstrates a high genetic barrier to resistance allowing it to maintain activity against variants with INSTI resistance. ${ }^{1-5}$ Currently, BIC $50 \mathrm{mg}$ daily is available only as a fixed dose combination with tenofovir alafenamide (TAF) $25 \mathrm{mg}$ daily and emtricitabine (FTC) $200 \mathrm{mg}$ daily (B/F/TAF).
Correspondence: Lucas Hill University of California San Diego Skaggs School of Pharmacy and Pharmaceutical Sciences, 200 W. Arbor Drive \#8765, San Diego, CA 92103-8765, USA

Tel + I 6195434995

Fax + I 619543784 I

Email luhill@ucsd.edu 
In this review, we aimed to 1) review the available literature supporting approved and potential off-label use of BIC, 2) discuss the clinical situations in which it might be used, and 3) review some of the unanswered questions about its place in therapy.

\section{Evidence in treatment-naïve PLWH}

BIC first demonstrated promise in a Phase Ib study of 20 HIV-infected ART naïve adults randomized to once daily BIC $(5,25,50$, or $100 \mathrm{mg})$ or placebo for 10 days. ${ }^{6}$ BIC showed rapid absorption, had a half-life period supporting once daily therapy, and was well tolerated with no discontinuations due to adverse events. Most importantly, significant reductions in plasma HIV-1 RNA occurred with all BIC doses. Thus BIC proceeded to a Phase II double-blind trial that randomized 98 participants $2: 1$ to receive oral once daily BIC $75 \mathrm{mg}$ or DTG $50 \mathrm{mg}$ with matching placebo plus the fixed dose combination of $200 \mathrm{mg}$ FTC and $25 \mathrm{mg}$ TAF for 48 weeks. ${ }^{7}$ Previously untreated PLWH aged $\geq 18$ years with HIV RNA $\geq 1,000$ copies per $\mathrm{mL}$ (c/mL), CD4 counts of at least 200 cells $/ \mu \mathrm{L}$, and estimated glomerular filtration (eGFR) rates of at least $70 \mathrm{~mL} / \mathrm{min}$ were included. Participants were excluded if they were hepatitis B or hepatitis C co-infected, had new AIDS-defining conditions within 30 days of screening, or were pregnant. Interestingly, $97 \%$ of participants in the BIC group achieved viral suppression at 24 and 48 weeks, vs $94 \%$ at 24 weeks and $91 \%$ at 48 weeks in the DTG arm. Treatmentemergent adverse events were reported by 55 (85\%) of 65 participants in the BIC group vs $22(67 \%)$ of 33 in the DTG group. The most common adverse events were diarrhea ( 8 $[12 \%]$ vs $4[12 \%])$ and nausea $(5[8 \%]$ vs $4[12 \%])$ in the $\mathrm{BIC}$ and DTG groups, respectively. These promising results then led to two Phase III trials of B/F/TAF.

Gallant et al conducted a multicenter non-inferiority study in Europe, Latin America, and North America (Trial 1489) where participants $(n=629)$ were randomly assigned to coformulated B/F/TAF or co-formulated DTG $50 \mathrm{mg}$, abacavir $600 \mathrm{mg}$ (ABC), and lamivudine $300 \mathrm{mg}$ (3TC), with matching placebo, once daily for 144 weeks. ${ }^{8}$ Eligibility criteria included treatment-naïve HIV-1 infected adults, HIV-1 RNA $\geq 500 \mathrm{c} / \mathrm{mL}$, HLA-B*5701-negative, and eGFR rate of $\geq 50$ $\mathrm{mL} / \mathrm{min}$. Patients with hepatitis B infection were excluded. Randomization was stratified by HIV-1 RNA $(\leq 100,000 \mathrm{c} /$ $\mathrm{mL},>100,000$ to $\leq 400,000 \mathrm{c} / \mathrm{mL}$, or $>400,000 \mathrm{c} / \mathrm{mL})$, CD4 count ( $<50$ cells $/ \mu \mathrm{L}, 50-199$ cells $/ \mu \mathrm{L}$, or $\geq 200$ cells $/ \mu \mathrm{L})$, and region (USA or ex-USA). Study participants were predominantly males (90\%-91\%), white (57\%), with median CD4 $444-450$ cells $/ \mu \mathrm{L}$. Both the arms demonstrated a high level of viral suppression at 48 weeks with $92 \%$ of participants in the $\mathrm{B} / \mathrm{F} / \mathrm{TAF}$ arm and $93 \%$ of participants in the DTG/ ABC/3TC arm demonstrating non-inferiority $(P=0.78)$. The DTG arm had numerically higher suppression rates in certain populations such as patients with viral loads $>100,000 \mathrm{c} / \mathrm{mL}$ ( $86 \%$ vs $94 \%$ ), CD4 counts $<200$ cells/ $\mu \mathrm{L}$ (95\% vs $100 \%$ ), and those with poor adherence (84\% vs 90\%). However, these differences were not statistically significant. Adverse events were less common in the $\mathrm{B} / \mathrm{F} / \mathrm{TAF}$ group vs the DTG/ ABC/3TC group (26\% vs $40 \%$ ) driven predominantly by the higher incidence of drug-related nausea in the DTG/ ABC/3TC group ( $5 \%$ vs $17 \% ; P<0.001)$.

In a second Phase III randomized controlled clinical trial (Trial 1490), Sax et al evaluated B/F/TAF for non-inferiority compared to DTG+F/TAF in 645 participants. ${ }^{9}$ This study focused on treatment naïve HIV-infected adults with HIV-1 RNA $\geq 500 \mathrm{c} / \mathrm{mL}$ and eGFR $\geq 30 \mathrm{~mL} / \mathrm{min}$, but also allowed chronic hepatitis B virus and hepatitis C co-infection. Similar to Trial 1489 , the study population was predominantly male (88\%-89\%), white $(57 \%-60 \%)$, and had a median CD4 $440-441$ cells $/ \mu \mathrm{L}$. At week $48,89 \%$ of participants in the BIC group and $93 \%$ in the DTG group achieved viral suppression showing non-inferiority of BIC regimen to the DTG regimen $(P=0.12)$. Again, study drug-related adverse events were less common in the BIC group (18\%) than in the DTG group (26\%) with the most common adverse events being headache, diarrhea, and nausea.

A pooled efficacy and resistance analysis of the two Phase III trials demonstrated that treatment with $\mathrm{B} / \mathrm{F} / \mathrm{TAF}, \mathrm{DTG} /$ $\mathrm{ABC} / 3 \mathrm{TC}$, or DTG+F/TAF was highly efficacious through week 48 with no development of resistance. ${ }^{10}$ Pre-existing drug resistance did not affect the efficacy outcomes and no participants developed resistance to study drugs on $\mathrm{B} / \mathrm{F} / \mathrm{TAF}$ or in any other treatment group. Collectively, these studies (summarized in Table 1) confirm the efficacy of B/F/TAF in treatment-naïve patients and lead to the Department of Health and Human Services recommending B/F/TAF as a preferred treatment regimen in treatment-naïve PLWH.,

\section{Evidence in treatment-experienced PLWH}

BIC use in PLWH who are treatment experienced is limited to studies that evaluate switching ART in PLWH who are virologically suppressed with no known resistance to any component in B/F/TAF (summarized in Table 2). As such, the outcomes included virologic suppression, and other clinically relevant outcomes including kidney function, cholesterol, and other adverse drug effects. Trial 1844, a 
Table I Summary of treatment-naïve studies

\begin{tabular}{|c|c|c|c|}
\hline Trial & Study design & Population & Outcome \\
\hline $\begin{array}{l}\text { Antiviral Activity, Safety, } \\
\text { and Pharmacokinetics } \\
\text { of Bictegravir as I0-Day } \\
\text { Monotherapy in HIV-I- } \\
\text { Infected Adults }\end{array}$ & $\begin{array}{l}\text { - Phase lb study evaluating the } \\
\text { antiviral activity, safety, and } \\
\text { pharmacokinetics } \\
\text { - Six groups treated for } 10 \text { days } \\
\text { - BIC } 5,25,50,100 \mathrm{mg} \text { or placebo } \\
\text { once daily }\end{array}$ & $\begin{array}{l}\text { Inclusion: } \\
\text { - Previously untreated adults } \\
\text { aged } \geq 18 \text { years with HIV-I } \\
\text { infections }\end{array}$ & $\begin{array}{l}\text { - Significant reductions in plasma HIV-I RNA } \\
\text { from baseline at day II for all BIC doses } \\
\text { compared with placebo and increased } \\
\text { BIC exposures correlated with increased } \\
\text { reduction in plasma HIV-I RNA from baseline } \\
\text { - Well tolerated with no discontinuations } \\
\text { due to adverse events } \\
\text { - Displayed rapid absorption and a half-life } \\
\text { supporting once daily therapy }\end{array}$ \\
\hline $\begin{array}{l}\text { Safety and Efficacy } \\
\text { of Bictegravir + } \\
\text { Emtricitabine/Tenofovir } \\
\text { Alafenamide Versus } \\
\text { Dolutegravir + } \\
\text { Emtricitabine/Tenofovir } \\
\text { Alafenamide in HIV-I- } \\
\text { Infected, Antiretroviral } \\
\text { Treatment-Naïve Adults }\end{array}$ & $\begin{array}{l}\text { - Phase II } \\
\text { - Two groups treated for } 48 \\
\text { weeks } \\
\text { - BIC } 75 \mathrm{mg}+\text { FTC } 200 \mathrm{mg} / \mathrm{TAF} \\
25 \mathrm{mg}=65 \\
\text { - DTG } 50 \mathrm{mg}+\text { FTC } 200 \mathrm{mg} / \\
\text { TAF } 25 \mathrm{mg}=33 \\
\text { - Primary outcome } \\
\text { - Proportion of participants with } \\
\text { HIV-I RNA }<50 \text { copies } / \mathrm{mL} \text { at } \\
\text { week } 24\end{array}$ & $\begin{array}{l}\text { Inclusion: } \\
\text { - Previously untreated adults } \\
\text { aged } \geq 18 \text { years with HIV-I } \\
\text { infection } \\
\text { Exclusion: } \\
\text { - Hepatitis B-co-infected } \\
\text { - Hepatitis C-co-infected } \\
\text { - New AIDS-defining } \\
\text { conditions within } 30 \text { days of } \\
\text { screening } \\
\text { - Pregnant }\end{array}$ & $\begin{array}{l}\text { - At week } 24,63 \text { ( } 96.9 \%) \text { of } 65 \text { in the BIC } \\
\text { group had HIV-I RNA }<50 \text { vs } 3 \text { I c/mL } \\
\text { ( } 93.9 \%) \text { of } 33 \text { in the DTG group (weighted } \\
\text { difference } 2.9 \%, 95 \% \mathrm{Cl}-8.5-14.2 ; P=0.50) \\
\text { - Adverse events } \\
\text { - } 55 \text { ( } 85 \% \text { ) of } 65 \text { participants in the BIC + } \\
\text { FTC/TAF group vs } 22(67 \%) \text { of } 33 \text { in the } \\
\text { DTG + FTC/TAF group } \\
\text { - Diarrhea was most common }\end{array}$ \\
\hline $\begin{array}{l}\text { Trial I489: Safety and } \\
\text { Efficacy of Bictegravir/ } \\
\text { Emtricitabine/Tenofovir } \\
\text { Alafenamide Versus } \\
\text { Abacavir/Dolutegravir/ } \\
\text { Lamivudine in HIV-I- } \\
\text { Infected, Antiretroviral } \\
\text { Treatment-Naïve Adults }\end{array}$ & $\begin{array}{l}\text { - Phase III, non-inferiority } \\
\text { - Two groups treated for I } 44 \\
\text { weeks } \\
\text { - BIC } 50 \mathrm{mg}, \text { FTC } 200 \mathrm{mg} \text {, and } \\
\text { TAF } 25 \mathrm{mg}=314 \\
\text { - DTG } 50 \mathrm{mg}, \text { ABC } 600 \mathrm{mg} \text {, and } \\
\text { 3TC } 300 \mathrm{mg}=315 \\
\text { - Primary endpoint: proportion of } \\
\text { participants with HIV-I RNA <50 } \\
\text { copies/mL at week } 48\end{array}$ & $\begin{array}{l}\text { Inclusion: } \\
\text { - Previously untreated adults } \\
\text { aged } \geq 18 \text { with HIV-I } \\
\text { infection } \\
\text { - HLA-B*570 I-negative } \\
\text { - eGFR rate of } \geq 50 \mathrm{~mL} / \mathrm{min} \\
\text { - Screening genotypes } \\
\text { showing sensitivity to FTC, } \\
\text { TAF, } 3 T C \text {, and } A B C \\
\text { Exclusion: } \\
\text { - Hepatitis B virus infection }\end{array}$ & $\begin{array}{l}\text { - At week } 48, \mathrm{HIV}-\mathrm{I} \text { RNA }<50 \mathrm{c} / \mathrm{mL} \text { was } \\
\text { achieved in } 92.4 \% \text { of patients }(290 / 3 \mathrm{I} 4) \\
\text { in the } \mathrm{B} / \mathrm{F} / \mathrm{TAF} \text { group and } 93 \% \text { of patients } \\
(293 / 3 \mathrm{I} 5) \text { in the } \mathrm{DTG} / \mathrm{ABC} / 3 \mathrm{TC} \text { group } \\
(\mathrm{Cl}-4.8-3.6 ; P=0.78) \text {, demonstrating non- } \\
\text { inferiority of B/F/TAF to DTG/ABC/3TC } \\
\text { - Less nausea in patients given } \mathrm{B} / \mathrm{F} / \mathrm{FTC} \text { than } \\
\text { in those given DTG/ABC/3TC }(10 \% \text { [n=32] } \\
\text { vs } 23 \%[\mathrm{n}=72] ; P<0.000 \mathrm{I})\end{array}$ \\
\hline $\begin{array}{l}\text { Trial I490: Safety and } \\
\text { Efficacy of Bictegravir/ } \\
\text { Emtricitabine/Tenofovir } \\
\text { Alafenamide Versus } \\
\text { Dolutegravir + } \\
\text { Emtricitabine/Tenofovir } \\
\text { Alafenamide in HIV-I } \\
\text { Infected, Antiretroviral } \\
\text { Treatment-Naïve Adults }\end{array}$ & $\begin{array}{l}\text { - Phase III, non-inferiority } \\
\text { - Two groups treated for } 48 \\
\text { weeks } \\
\text { - BIC } 50 \mathrm{mg} \text { plus FTC } 200 \mathrm{mg} \text {, } \\
\text { and TAF } 25 \mathrm{mg}=320 \\
\text { - DTG } 50 \mathrm{mg} \text { plus FTC } 200 \mathrm{mg} \\
\text { and TAF } 25 \mathrm{mg}=325 \\
\text { - Primary endpoint: proportion of } \\
\text { participants with HIV-I RNA <50 } \\
\text { copies per } \mathrm{mL} \text { at week } 48\end{array}$ & $\begin{array}{l}\text { Inclusion: } \\
\text { - Previously untreated adults } \\
\text { aged } \geq 18 \text { years with HIV-I } \\
\text { infection } \\
\text { - } \text { eGFR } \geq 30 \mathrm{~mL} / \mathrm{min} \\
\text { - Chronic hepatitis B virus or } \\
\text { hepatitis C co-infection was } \\
\text { allowed }\end{array}$ & $\begin{array}{l}\text { - At week } 48, \mathrm{HIV}-\mathrm{I} \text { RNA }<50 \mathrm{c} / \mathrm{mL} \text { was } \\
\text { achieved in } 286(89 \%) \text { of } 320 \text { participants in } \\
\text { the BIC group and } 302(93 \%) \text { of } 325 \text { in the } \\
\text { DTG group }(\mathrm{Cl}-7.9-1.0, P=0.12) \\
\text { - Demonstrated non-inferiority of the BIC } \\
\text { regimen to the DTG regimen } \\
\text { - Adverse events: } \\
\text { - Incidence and severity of adverse events } \\
\text { were similar between groups } \\
\text { - Study drug-related adverse events were } \\
\text { less common in the BIC group than in the } \\
\text { DTG group (57 [ } 18 \% \text { of } 320 \text { vs } 83 \text { [26\%] } \\
\text { of } 325, P=0.022)\end{array}$ \\
\hline $\begin{array}{l}\text { Pooled Week } 48 \\
\text { Efficacy and Baseline } \\
\text { Resistance: B/F/TAF } \\
\text { in Treatment-Naïve } \\
\text { Patients (Abstract) }\end{array}$ & $\begin{array}{l}\text { - HIV-I genotypic data at } \\
\text { screening were obtained for all } \\
\text { participants and consisted of } \\
\text { population genotype of RT and } \\
\text { PR } \\
\text { - Resistance analysis population } \\
\text { included confirmed virologic } \\
\text { failure or HIV viral load }>200 \mathrm{cl} \\
\mathrm{mL} \text { at week } 48\end{array}$ & $\begin{array}{l}\text { Study I489 and I } 490 \\
\text { participants }\end{array}$ & $\begin{array}{l}\text { - Treatment with B/F/TAF, DTG/ABC/3TC, } \\
\text { or DTG+F/TAF was highly efficacious } \\
\text { through week } 48 \text { with no subject } \\
\text { developing resistance to the study drug } \\
\text { - Rapid viral load suppression approached } \\
80 \% \text { of patients at week } 4 \\
\text { - HIV-I subtype did not affect efficacy } \\
\text { outcome } \\
\text { - Pre-existing drug resistance did not affect } \\
\text { efficacy outcome } \\
\text { - These results provide support for future } \\
\text { studies of BIC and B/F/TAF in INSTI- and } \\
\text { NRTI- resistant populations }\end{array}$ \\
\hline
\end{tabular}

Abbreviations: 3TC, lamivudine; ABC, abacavir; B/F/TAF, bictegravir/emtricitabine/tenofovir alafenamide single tablet; BIC, bictegravir; DTG, dolutegravir; FTC, emtricitabine; INSTI, integrase strand transfer inhibitor; NRTI, nucleoside reverse transcriptase inhibitor; PR, protease; RT, reverse transcriptase; TAF, tenofovir alafenamide. 
Table 2 Summary of treatment-experienced switch studies

\begin{tabular}{|c|c|c|c|}
\hline Trial & Study design & Population & Outcome \\
\hline $\begin{array}{l}\text { Trial I844: Safety and } \\
\text { Efficacy of Switching From } \\
\text { Dolutegravir and ABC/3TC } \\
\text { or DTG/ABC/3TC } \\
\text { to B/F/TAF in HIV-I } \\
\text { Infected Adults Who Are } \\
\text { Virologically Suppressed }\end{array}$ & $\begin{array}{l}\text { - Phase III, non-inferiority } \\
\text { - Two groups treated } \\
\text { - } \text { B/F/TAF 50/200/25 mg daily }=282 \\
\text { - DTG/ABC/3TC 50/600/300 mg } \\
\text { daily =28I } \\
\text { - Primary endpoint: proportion of } \\
\text { participants with HIV-I RNA } \geq 50 \mathrm{cl} \\
\mathrm{mL} \text { at week } 48\end{array}$ & $\begin{array}{l}\text { Inclusion: } \\
\text { - HIV-I-infected adults } \\
\text { - Virologically suppressed } \\
\text { (HIV-I RNA }<50 \mathrm{c} / \mathrm{mL} \text { for } \\
\geq 3 \text { months) on regimen } \\
\text { containing DTG, ABC, and } \\
3 T C \\
\text { - eGFR } \geq 50 \mathrm{~mL} / \mathrm{min} \\
\text { Exclusion: } \\
\text { - Active HBV infection } \\
\text { - Resistance to study drugs }\end{array}$ & $\begin{array}{l}\text { - At week } 48, \mathrm{HIV}-\mathrm{I} \mathrm{RNA} \geq 50 \mathrm{cl} \\
\mathrm{mL} \text { occurred in } 3(\mathrm{I} . \mathrm{I} \%) \text { of } 282 \\
\text { participants in the BIC group and } \\
\mathrm{I}(0.4 \%) \text { of } 28 \mathrm{I} \text { participants in the } \\
\mathrm{DTG} / \mathrm{ABC} / 3 \mathrm{TC} \text { group }(\mathrm{P}=0.62) \\
\text { - Switching to B/F/TAF was non- } \\
\text { inferior to remaining on DTG/ } \\
\text { ABC/3TC } \\
\text { - No participant developed treatment } \\
\text { emergent resistance } \\
\text { - B/F/TAF was well tolerated with } \\
\text { adverse events comparable between } \\
\text { arms at week } 48 \\
\end{array}$ \\
\hline $\begin{array}{l}\text { Trial I878: Safety and } \\
\text { Efficacy of Switching from } \\
\text { Regimens Consisting of } \\
\text { Boosted Atazanavir or } \\
\text { Darunavir Plus Either } \\
\text { Emtricitabine/Tenofovir } \\
\text { or Abacavir/Lamivudine to } \\
\text { Bictegravir/Emtricitabine/ } \\
\text { Tenofovir Alafenamide in } \\
\text { Virologically Suppressed } \\
\text { HIV-I-Infected Adults }\end{array}$ & $\begin{array}{l}\text { - Phase III, non-inferiority } \\
\text { - Two groups } \\
\text { - B/F/TAF once daily }=290 \\
\text { - Continue on baseline regimen of } \\
\text { either boosted DRV or ATV + } 2 \\
\text { NRTIs=287 } \\
\text { - Primary endpoint: Proportion of } \\
\text { participants with plasma HIV-I } \\
\text { RNA } \geq 50 \mathrm{c} / \mathrm{mL} \text { at week } 48\end{array}$ & $\begin{array}{l}\text { Inclusion: } \\
\text { - HIV-I-infected adults } \\
\text { - Virologically suppressed } \\
\text { receiving DRV or ATV + } 2 \\
\text { NRTIs (ABC/3TC or FTC/ } \\
\text { TDF) } \\
\text { - HIV-I RNA }<50 \mathrm{c} / \mathrm{mL} \text { for } \\
6 \text { months } \\
\text { - eGFR } \geq 50 \mathrm{~mL} / \mathrm{min}\end{array}$ & $\begin{array}{l}\text { - At week } 48, \mathrm{HIV}-\mathrm{I} \mathrm{RNA} \geq 50 \mathrm{cl} \\
\mathrm{mL} \text { occurred in } 5 \text { (I.7\%) of } 290 \\
\text { participants in the } \mathrm{BIC} \text { group and } \\
5 \text { (I.7\%) of the } 287 \text { in the protease } \\
\text { inhibitor group }(\mathrm{Cl}-2.5-2.5, P=I .00) \\
\text { - Switching to B/F/TAF was non } \\
\text { inferior to remaining on DRV or } \\
\text { ATV + } 2 \text { NRTls } \\
\text { - No treatment-emergent resistance } \\
\text { was found in B/F/TAF group } \\
\text { - No difference in grade } 3 \text { or } 4 \\
\text { laboratory abnormalities was } \\
\text { observed between the arms except } \\
\text { for bilirubin abnormalities due to } \\
\text { ATV use }\end{array}$ \\
\hline $\begin{array}{l}\text { Resistance Analysis of the } \\
\text { B/F/TAF Switch Studies }\end{array}$ & $\begin{array}{l}\text { - Plasma viral RNA genotyping and } \\
\text { phenotyping of PR, RT, and IN were } \\
\text { attempted for all participants in the } \\
\text { RAP } \\
\text { - Baseline proviral DNA genotyping } \\
\text { was conducted retrospectively on } \\
\text { select participants: } \\
\text { - Participants included in the RAP } \\
\text { - Participants who switched to B/F/ } \\
\text { TAF with } \geq 10 \text { years prior ARV } \\
\text { treatment or unknown ARV } \\
\text { initiation date }\end{array}$ & $\begin{array}{l}\text { Participants from studies } \\
\text { I844 and } 1878\end{array}$ & $\begin{array}{l}\text { - No participants in the B/F/TAF or } \\
\text { ABC/DTG/3TC groups developed } \\
\text { resistance } \\
\text { - One participant in the PI + } 2 \text { NRTI } \\
\text { group on boosted DRV + ABC/3TC } \\
\text { had virologic failure with treatment- } \\
\text { emergent L74V in RT } \\
\text { - High rates of virologic suppression } \\
\text { were maintained among participants } \\
\text { who switched to B/F/TAF ( } 93 \% \\
\text { overall), regardless of preexisting } \\
\text { resistance substitutions }\end{array}$ \\
\hline $\begin{array}{l}\text { Safety and Efficacy of } \\
\text { Switching to a fixed dose } \\
\text { combination of B/F/TAF } \\
\text { from E/C/F/TAF, E/C/F/ } \\
\text { TDF, or ATV + RTV + } \\
\text { FTC/TDF in Virologically } \\
\text { Suppressed HIV-I-Infected } \\
\text { Women }\end{array}$ & $\begin{array}{l}\text { - Phase III, non-inferiority } \\
\text { - Two groups: } \\
\text { - B/F/TAF once daily }=234 \\
\text { - Remain on baseline regimen }=236 \\
\text { - Primary endpoint: proportion of } \\
\text { participants with HIV-I RNA } \geq 50 \mathrm{cl} \\
\mathrm{mL} \text { at week } 48 \\
\text { - Secondary endpoint: proportion of } \\
\text { participants with HIV-I RNA }<50 \mathrm{cl} \\
\mathrm{mL} \text { at week } 48\end{array}$ & $\begin{array}{l}\text { Inclusion: } \\
\text { - HIV-I-infected adults } \\
\text { - Virologically suppressed } \\
\text { women (HIV-I RNA }<50 \\
\text { c/mL for } \geq 6 \text { months) on } \\
\text { E/C/F/TAF or E/C/F/TDF } \\
\text { or ATV + RTV + F/TDF } \\
\text { - Baseline } \mathrm{CrCl} \geq 50 \mathrm{~mL} / \mathrm{min}\end{array}$ & $\begin{array}{l}\text { - At week } 48, \mathrm{HIV}-\mathrm{I} \text { RNA } \geq 50 \mathrm{cl} \\
\mathrm{mL} \text { occurred in } 4 \text { ( } 2 \%) \text { of } 234 \\
\text { participants in the B/F/TAF and } 4 \\
\text { ( } 2 \% \text { ) of } 236 \text { in the same baseline } \\
\text { regimen group } \\
\text { - Switching to B/F/TAF was non- } \\
\text { inferior to continuing standard of } \\
\text { care } \mathrm{PI} \text { and INSTI-based regimens at } \\
\text { week } 48 \\
\text { - No treatment-emergent resistance } \\
\text { was observed in women receiving } \\
\text { B/F/TAF } \\
\text { - B/F/TAF was well tolerated with } \\
\text { no adverse events leading to } \\
\text { discontinuation }\end{array}$ \\
\hline
\end{tabular}


Table 2 (Continued)

\begin{tabular}{|c|c|c|c|}
\hline Trial & Study design & Population & Outcome \\
\hline $\begin{array}{l}\text { Bictegravir/FTC/TAF } \\
\text { Single-Tablet Regimen in } \\
\text { Adolescents: Week-24 } \\
\text { Results }\end{array}$ & $\begin{array}{l}\text { - Phase II/III, open-label, multicenter, } \\
\text { multicohort, single-arm treated for } 48 \\
\text { weeks } \\
\text { - B/F/TAF group }=24 \\
\text { - Primary endpoint: to determine the } \\
\text { plasma PK of BIC and evaluate the } \\
\text { safety and tolerability of B/F/TAF } \\
\text { through } 24 \text { weeks of treatment in } \\
\text { HIV-I-infected adolescents } \\
\text { - Secondary endpoint: to evaluate the } \\
\text { safety and tolerability of B/F/TAF } \\
\text { through } 48 \text { weeks, and its antiviral } \\
\text { activity at } 24 \text { and } 48 \text { weeks }\end{array}$ & $\begin{array}{l}\text { Inclusion: } \\
\text { - HIV-I-infected } \\
\text { - Virologically suppressed } \\
\text { adolescents } \\
\text { - Aged } 12 \text { to }<18 \text { years } \\
\text { - Weight } \geq 35 \mathrm{~kg} \\
\text { - HIV-I RNA <50 c/mL for } \\
\text { - C6 months } \\
\text { - eGFR } \geq 90 \mathrm{~mL} / \mathrm{min}\end{array}$ & $\begin{array}{l}\text { - Exposures of FTC and TAF were } \\
\text { within the safe and efficacious range } \\
\text { with similar BIC exposures observed } \\
\text { in adolescents and adults } \\
\text { - Maintenance of virologic suppression } \\
\text { at week } 24: \text { HIV-I RNA }<50 \mathrm{c} / \mathrm{mL} \text { in } \\
\text { all } 24 \text { participants ( } 100 \%) \\
\text { - Data support further pediatric } \\
\text { studies of B/F/TAF, which may be an } \\
\text { important unboosted INSTI option } \\
\text { for HIV-infected adolescents and } \\
\text { children }\end{array}$ \\
\hline
\end{tabular}

Abbreviations: 3TC, lamivudine; ABC, abacavir; ARV, antiretroviral; ATV, atazanavir; BIC, bictegravir; B/F/TAF, bictegravir/emtricitabine/tenofovir alafenamide single tablet; $\mathrm{CrCl}$, creatinine clearance; DRV, darunavir; DTG, dolutegravir; E/C/F/TAF, elvitegravir/cobicistat/emtricitabine/tenofovir alafenamide; E/C/F/TDF, elvitegravir/cobicistat/ emtricitabine/tenofovir disoproxil fumarate; FTC, emtricitabine; IN, integrase; INSTI, integrase strand transfer inhibitor; PK, pharmacokinetic; PR, protease; RAP, resistance analysis population; RT, reverse transcriptase; RTV, ritonavir; TAF, bictegravir; TAF, tenofovir alafenamide; PI, protease inhibitor.

Phase III, randomized, double-blind, multicenter study evaluated 282 participants who switched from $\mathrm{DTG}+\mathrm{ABC} / 3 \mathrm{TC}$ or $\mathrm{DTG} / \mathrm{ABC} / 3 \mathrm{TC}$ to $\mathrm{B} / \mathrm{F} / \mathrm{TAF}$ and 281 who continued DTG + $\mathrm{ABC} / 3 \mathrm{TC}$ or DTG/ABC/3TC. ${ }^{11}$ Patients with active hepatitis $B$ co-infection or eGFR $<50 \mathrm{~mL} / \mathrm{min}$ were excluded from participation. As in previous studies, the participants were predominantly male ( $88 \%-90 \%)$, white $(73 \%)$, with median CD4 661-732 cells/ $\mu \mathrm{L}$. In the FDA snapshot analysis at 48 weeks, $1.1 \%$ in the BIC arm and $0.4 \%$ in the DTG arm had HIV-1 RNA $\geq 50 \mathrm{c} / \mathrm{mL}$ for a difference of $0.7 \%$ meeting non-inferiority end-point. Fewer participants in the BIC arm reported drug-related adverse events $(8 \%)$ as compared to the DTG arm $(16 \%)(P=0.01)$. The most common adverse events were headache, abnormal dreams, diarrhea, fatigue, flatulence, nausea, and insomnia. A statistically significant difference in the change in eGFR at week 48 was observed, with a $1 \mathrm{~mL} / \mathrm{min}$ increase in the BIC arm and a $1.8 \mathrm{~mL} /$ min decrease in the DTG arm $(P=0.001)$; however, no significant differences in markers of tubular damage were observed (ie, urine albumin:creatinine ratio, retinol binding protein:creatinine ratio, or $\beta$-2-microglobulin:creatinine ratio). In addition, there were no significant differences in spine and hip bone mineral density, total cholesterol, LDL, or HDL. The BIC group did have a slight reduction in triglyceride levels of $5 \mathrm{mg} / \mathrm{dL}$ compared to a $3 \mathrm{mg} / \mathrm{dL}$ increase in the DTG group $(P=0.028)$. Overall, the clinical relevance of these differences remains unknown.

The efficacy of switching from boosted protease inhibitors to $\mathrm{B} / \mathrm{F} / \mathrm{TAF}$ has also been evaluated (Trial 1878) in a Phase III multicenter, randomized, open-label trial. ${ }^{12}$
Participants on either ritonavir-boosted darunavir (DRV) or atazanavir (ATV) in combination with two nucleoside reverse transcriptase inhibitors (NRTIs) were randomized to stay on their current regimen $(n=287)$ or switch to $B / F / T A F ~(n=290)$. Again, the study included primarily white males with well controlled HIV. A slightly higher proportion of participants were on a DRV-based regimen $(54 \%-57 \%)$ than on an ATVbased regimen $(43 \%-46 \%)$ but most were combined with a NRTI backbone of tenofovir disoproxil fumarate (TDF)/FTC. The primary outcome was the proportion of patients with HIV-1 RNA $\geq 50 \mathrm{c} / \mathrm{mL}$ at week 48 using the FDA snapshot analysis with a non-inferiority margin of $4 \%$. At week 48 , $1.7 \%$ in both the arms had HIV-1 RNA $\geq 50 \mathrm{c} / \mathrm{mL}$ demonstrating non-inferiority. In the BIC arm, 92.1\% were virologically suppressed at week 48 compared to $88.9 \%$ in the boosted protease inhibitor (PI) arm demonstrating a non-statistically significant difference. Again, no treatment-emergent resistance occurred in the participants switched to B/F/TAF. In terms of safety, $12 \%$ in the BIC arm and $4 \%$ in the boosted $\mathrm{PI}$ arm reported an adverse event, with the difference driven primarily by headache ( $12 \%$ vs $4 \%$ ); however, the majority were mild in severity. Overall, discontinuations due to adverse events were similar between the two arms. The median change in eGFR in the BIC arm was $-4.3 \mathrm{~mL} / \mathrm{min}$ vs $0.2 \mathrm{~mL} / \mathrm{min}$ in the boosted PI arm $(P<0.001)$. This observation was not anticipated given the demonstrated improvement in urine albumin to creatinine ratio when switching from TDF to a TAF-based regimen in this study ( $10 \% \mathrm{vs}-2 \%$ respectively). Thus, the authors hypothesized that eGFR differences were likely due to the inhibition of creatinine secretion by BIC. 
No differences in change from baseline in total cholesterol, LDL, or HDL cholesterol were observed between the two arms; however, switching to the BIC regimen resulted in a median change of $-6 \mathrm{mg} / \mathrm{dL}$ vs $4 \mathrm{mg} / \mathrm{dL}$ in triglycerides $(P=0.002)$ and a median change of -0.2 verses 0 in the total cholesterol: HDL ratio $(P=0.033)$.

In these two studies, participants with known resistance to the components of B/F/TAF were excluded; however, no genotype testing was done at screening and historical genotypes were only collected if available. To better evaluate if pre-existing HIV resistance to any components in B/F/TAF impacted study outcome, a pooled HIV resistance analysis of participants in these studies was conducted. ${ }^{13}$ The resistance analysis population included confirmed virologic failures (defined as two consecutive visits with HIV-1 RNA $\geq 50 \mathrm{c} / \mathrm{mL}$ and $\geq 200 \mathrm{c} / \mathrm{mL}$ at the confirmation visit or having a HIV-1 RNA $\geq 200 \mathrm{c} / \mathrm{mL}$ at week 48 ), that also had a phenotype, genotype, or proviral DNA genotype (archived genotype) and all participants who switched to $\mathrm{B} / \mathrm{F} / \mathrm{TAF}$ with $\geq 10$ years of ARV experience or unknown ARV start date who had a proviral DNA genotype. This resulted in 405 participants in the $\mathrm{B} / \mathrm{F} / \mathrm{TAF}$ arm, 125 patients in the PI +2 NRTI arm, and 138 in the $\mathrm{ABC} / 3 \mathrm{TC} / \mathrm{DTG}$ arm. In the total resistance cohort of 405 patients, 13\% had NRTI resistance, 18\% had non nucleoside reverse transcriptase inhibitor (NNRTI) resistance, and $6 \%$ had PI resistance at baseline. Only one participant in the $\mathrm{B} / \mathrm{F} / \mathrm{TAF}$ arm demonstrated primary (may have impact on INSTI susceptibility) INSTI resistance at baseline (T97A) but 51\% out of 170 evaluated had secondary (unlikely to impact INSTI susceptibility) INSTI resistance. The important take away from the analysis is that no participants in the B/F/TAF arm developed resistance, and 35/36 (97\%) of patients with archived FTC or TAF resistance $(5 / 5$ with K65R, 18/18 with M184V/I/T, 12/13 with M184V + other NRTI resistance, and 4/4 with $\geq 2$ TAMs) maintained viral suppression through week 48 .

Two other treatment-experienced studies involving B/F/ TAF have been conducted. The first (study 1961) included virologically suppressed women on elvitegravir/cobicistat/ FTC/TAF (E/C/F/TAF), elvitegravir/cobicistat/FTC/TDF (E/C/F/TDF), or TDF/FTC + ATV/ritonavir (ATV/r) and randomized them to stay on their current regimen $(n=236)$ or switch to $\mathrm{B} / \mathrm{F} / \mathrm{TAF}$ ( $\mathrm{n}=234) .{ }^{14}$ The primary endpoint was HIV-1 RNA $\geq 50 \mathrm{c} / \mathrm{mL}$ at week 48 using the FDA snapshot algorithm with a $4 \%$ non-inferiority margin. The median age of the female participants was 39-40 years, 37\% were black or African descent, 16\% Hispanic/Latino with median CD4 T-cell counts of $667-704$ cells $/ \mu \mathrm{L}$. In terms of ARV regimen at randomization, $53 \%$ were on $\mathrm{E} / \mathrm{C} / \mathrm{F} / \mathrm{TAF}, 42 \%$ were on $\mathrm{E} / \mathrm{C} / \mathrm{F} / \mathrm{TDF}$, and $5 \%$ were on $\mathrm{TDF} / \mathrm{FTC}+\mathrm{ATV} / \mathrm{r}$. For the primary outcome, $1.7 \%$ in each arm had HIV-1 RNA $\geq 50$ at week 48 demonstrating non-inferiority of $\mathrm{B} / \mathrm{F} /$ TAF. Again, no treatment-emergent resistance was observed in patients receiving $\mathrm{B} / \mathrm{F} / \mathrm{TAF}$. Similar rates of drug-related adverse events, $9 \%$ vs $6 \%$, and serious adverse events, $5 \%$ vs $6 \%$, were seen in the $\mathrm{B} / \mathrm{F} / \mathrm{TAF}$ and continuation of baseline regimen arms, respectively. Switching from a TDF- to a TAF-based regimen resulted in significant improvement in retinol binding protein:creatinine ratio and beta-2microglobulin:creatinine ratio which are tubular biomarkers suggesting improved kidney function. In addition, there was no difference in median change in eGFR between BIC arm compared to continuation of baseline arm $(-1.8 \%$ vs $-2.7 \%)$. The only significant difference in lipid parameters was a 10 $\mathrm{mg} / \mathrm{dL}$ decrease in triglycerides in the BIC arm vs a $4 \mathrm{mg} /$ $\mathrm{dL}$ increase in the continuation arm $(P<0.001)$.

The final switch study was conducted in children (age 6-11 years) and adolescents (age 12-17 years) who were suppressed on a regimen of two NRTIs plus a third agent. ${ }^{15}$ The primary endpoint was steady-state PK parameters at week 2 or 4 , but also included safety through week 24 , and the secondary endpoint was viral suppression at week 24 and 48. In the interim analysis in 24 adolescents, $100 \%$ maintained virologic suppression at week 24 . There was only one adverse event (grade 1 vomiting) attributed to $\mathrm{B} / \mathrm{F} / \mathrm{TAF}$ suggesting good tolerability in this small population of adolescents.

Other ongoing studies in treatment-experienced PLWH include a Phase III, randomized, double-blind, multicenter study in HIV-suppressed adults on DTG plus F/TDF or F/TAF randomized to stay on their current regimen or switch to $\mathrm{B} / \mathrm{F} /$ TAF. In this study, participants with any NRTI, NNRTI, or PI resistance will be included; however, they must have no documented INSTI resistance or confirmed virologic failure while on an INSTI regimen. In addition, there is a Phase III, multicenter, open-label, single-arm study in HIV-suppressed adults aged $\geq 65$ years who will be switched to B/F/TAF. Results for these studies are not yet available but will further inform the utility of B/F/TAF in treatment-experienced PLWH.

\section{PKs and drug interactions}

The PK of BIC and the other components of the single-tablet regimen allow for use in a broad population of patients. BIC has a plasma half-life period of 17.3 hours allowing for once daily dosing in combination with FTC and TAF which have intracellular half-lives of 39 and 150 hours, respectively. ${ }^{4}$ $\mathrm{BIC}$ is not renally eliminated and therefore does not have 
meaningful changes in plasma concentrations in patients with severe renal impairment. The PKs of TAF are also not significantly changed in patients with a creatinine clearance $(\mathrm{CrCl})$ down to $15 \mathrm{~mL} / \mathrm{min}$; however, due to the renal elimination of FTC, B/F/TAF is not recommended in patients with a $\mathrm{CrCl}<30 \mathrm{~mL} / \mathrm{min}^{1,4,16} \mathrm{BIC}$ and TAF have been studied in patients with moderate hepatic impairment (Child-Pugh B), but not in patients with severe hepatic impairment, and due to lack of data, they are not recommended in this population. FTC is not hepatically metabolized and is expected to be safe to use in patients with hepatic impairment. ${ }^{1,4,16}$

BIC is metabolized by UGT1A1 and CYP3A4 and may be susceptible to drug interactions with strong inducers or inhibitors of these enzymes. One important drug interaction is with rifampin, a strong CYP3A4 inducer. Studies suggest that when rifampin is provided concurrently with $\mathrm{B} / \mathrm{F} / \mathrm{TAF}$, BIC exposure is $60 \%$ lower with twice daily dosing and $80 \%$ lower when dosed once daily. ${ }^{17}$ Therefore, the use of B/F/TAF in combination with rifampin, rifabutin, or rifapentin as well as other potent inducers such as the anticonvulsants carbamazepine, oxcarbazepine, and phenytoin is not recommended. Of note, the use of TAF with rifampin is still being evaluated as TAF is a p-glycoprotein (P-gp) substrate and rifampin is a $\mathrm{P}$-gp inducer. A recent study suggested that although plasma concentrations of tenofovir are lowered (47\% reduction) when TAF is given with rifampin, the intracellular concentrations of tenofovir diphosphate were still $82 \%$ higher as compared to the intracellular concentrations achieved with TDF without the use of rifampin. ${ }^{18}$

Another important interaction to consider is the impact of polyvalent cations on the absorption of BIC. When BIC was given with antacids containing aluminum, magnesium, or calcium simultaneously in a fasted state, BIC exposure decreased almost $80 \%$, and when given 2 hours after the antacid, it decreased to $52 \%$. However, if BIC was given 2 hours before the antacid, the area under the curve (AUC) of BIC was decreased by only $13 \%$. When given with calcium or iron, BIC concentrations are not significantly altered even when given simultaneously as long as it is in a fed state. Therefore, BIC should be given 2 hours prior to aluminum, magnesium, or calcium containing antacids or simultaneously with calcium or iron as long as taken with food. ${ }^{4}$

Finally, BIC is an inhibitor of the drug transporters OCT2 and MATE1 that may impact other medications that are substrates for these transporters. In previous PK studies with DTG, also an OCT2 and MATE1 inhibitor, the combination of DTG and metformin resulted in an increase of about $80 \%$ in metformin exposure which is clinically significant. ${ }^{19}$ As compared to placebo, co-administration with BIC increased metformin AUC by $39 \%$ when studied in 32 healthy subjects. Metformin-induced increases in lactate were similar between placebo and BIC group, suggesting this interaction may not be clinically significant. ${ }^{20}$

\section{Comparison of available integrase inhibitors}

The introduction of the integrase inhibitor class in 2007 was a significant advancement in the treatment of HIV as it provided a new class of medications with a novel mechanism of action, and treatment options for PLWH with acquired drug resistance to multiple classes of ARVs. ${ }^{21}$ Literature extensively documents that INSTIs are very well tolerated and, with the exception of EVG which requires boosting by cobicistat or ritonavir, carry the advantage of limited drug interactions. ${ }^{22-27}$ The first-generation INSTIs include raltegravir (RAL) and EVG. In addition to limitations that require twice daily dosing of RAL and issues with drug interactions with boosted EVG, the first-generation INSTIs have a low genetic barrier to resistance. ${ }^{28}$ DTG, a second-generation INSTI has significant advantages over the first-generation INSTIs in that it can be dosed once daily in patients without documented or inferred INSTI resistance, has a high genetic barrier to resistance, limited drug interactions, and can be used in PLWH with INSTI resistance at doses of $50 \mathrm{mg}$ twice daily. ${ }^{29} \mathrm{BIC}$ carries similar advantages to DTG in that it is dosed once daily and has limited drug interactions. In vitro data evaluating BIC against 47 clinical isolates with INSTI resistance mutations suggests a high genetic barrier to resistance which is discussed below in more detail. ${ }^{30} \mathrm{BIC}$ is also the only unboosted integrase inhibitor that is available co-formulated with TAF/ FTC and is the smallest tablet size among the INSTI-based single-tablet regimens available. The primary limitation with BIC as compared to the other INSTI is that studies with BIC have been limited to either the treatment-naïve population or PLWH who are already suppressed on their current ARV regimen and switching to BIC. Unlike the other INSTIs, BIC has not been studied in treatment-experienced populations (Table 3). In addition, although BIC shows in vitro activity against INSTI-resistant strains, clinical trial data are absent to guide use in PLWH with documented or suspected INSTI resistance, as compared to DTG which carries an indication for PLWH with INSTI resistance. ${ }^{31}$

\section{Unanswered questions}

Despite significant clinical trial data in both treatmentnaïve and virologically suppressed treatment-experienced 


\begin{tabular}{|c|c|c|c|}
\hline 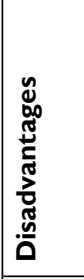 & 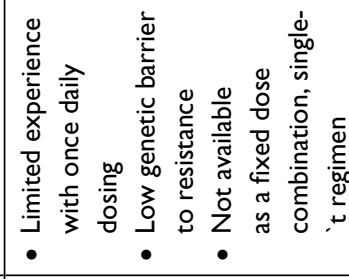 & 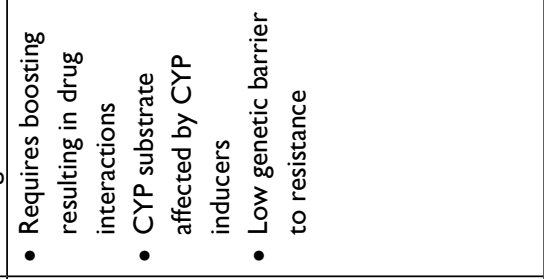 & 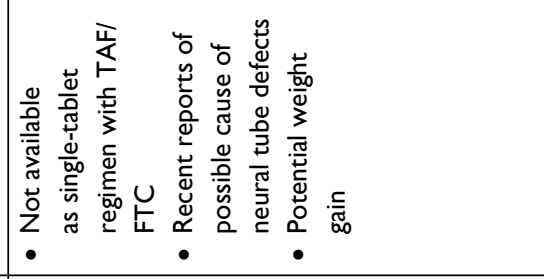 \\
\hline 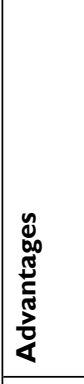 & 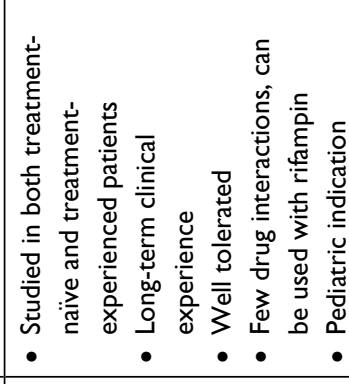 & 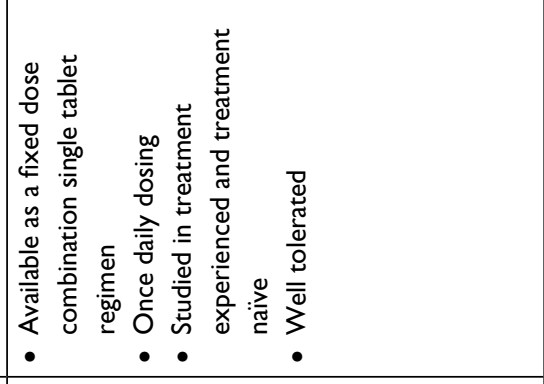 & 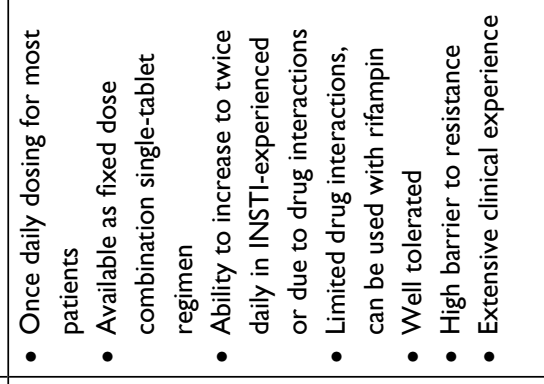 \\
\hline 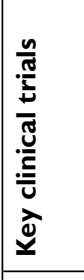 & 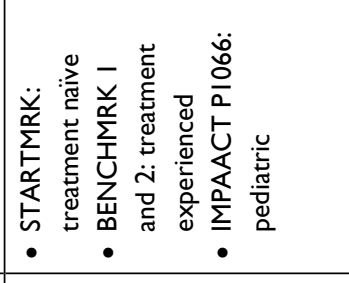 & 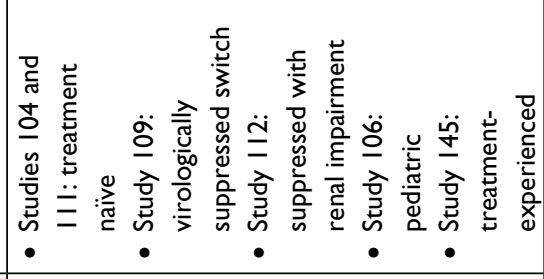 & 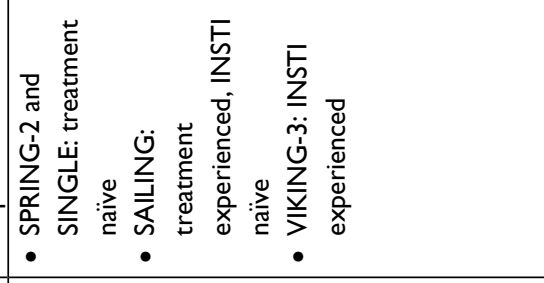 \\
\hline 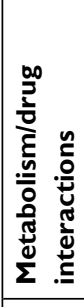 & 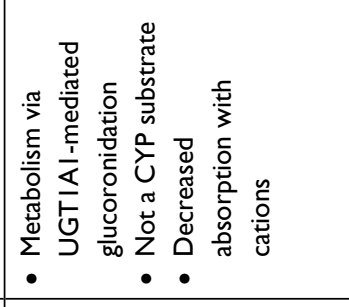 & 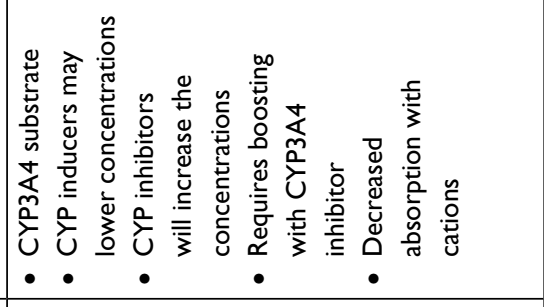 & 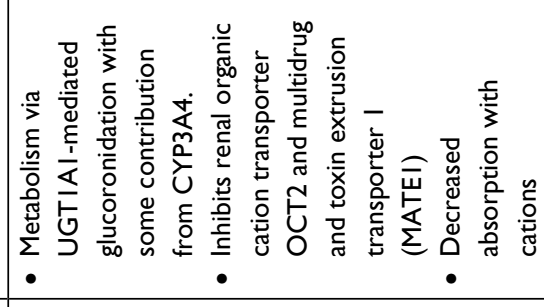 \\
\hline 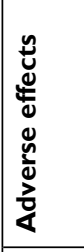 & 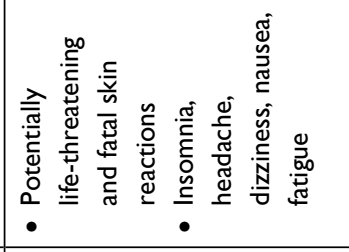 & 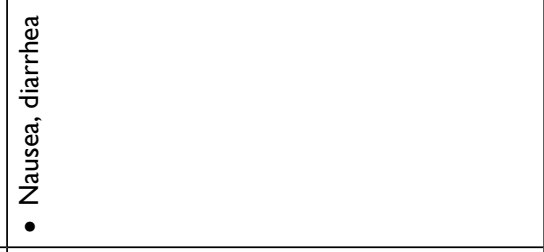 & 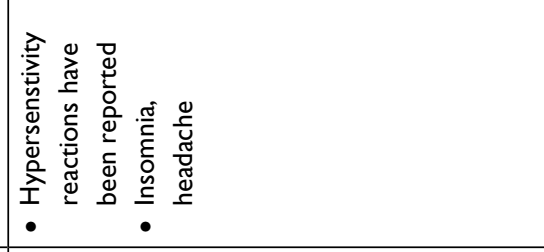 \\
\hline 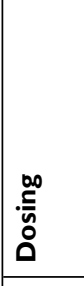 & 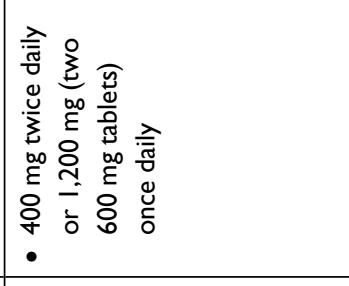 & 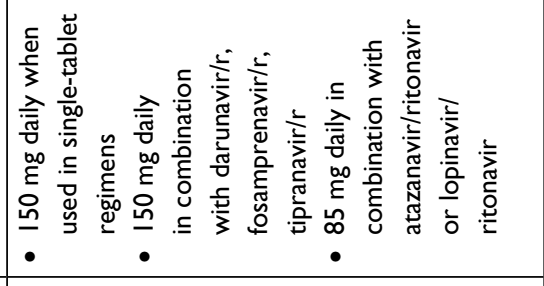 & 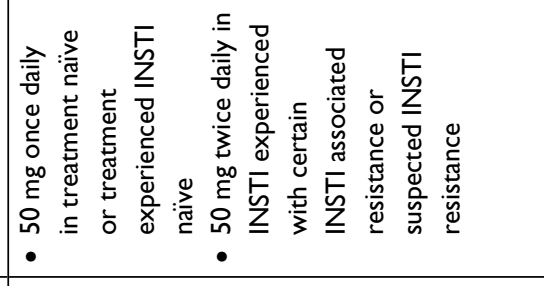 \\
\hline 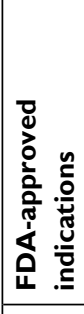 & 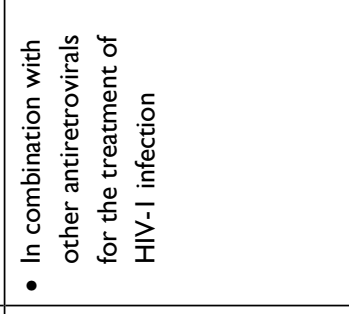 & 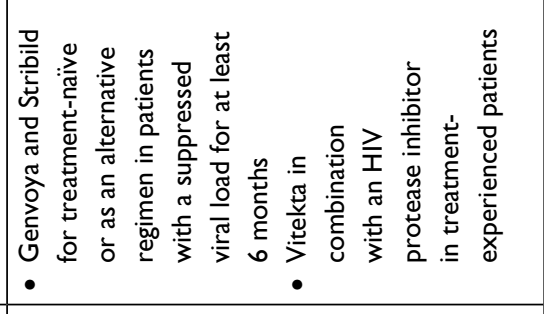 & 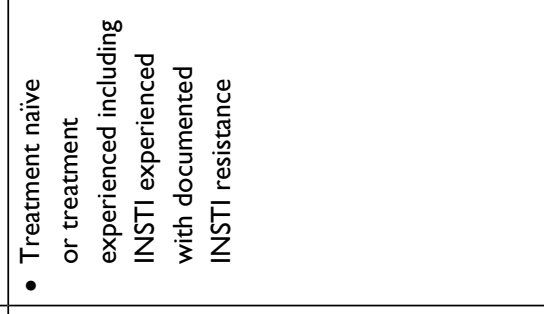 \\
\hline 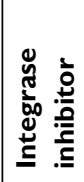 & 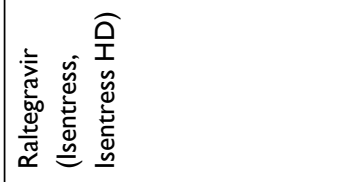 & 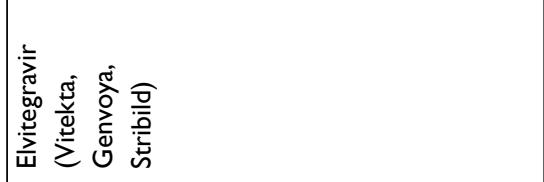 & 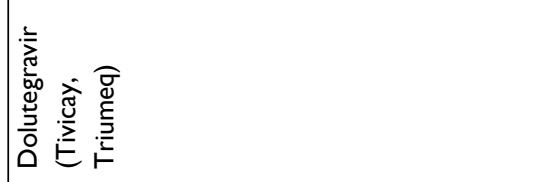 \\
\hline
\end{tabular}




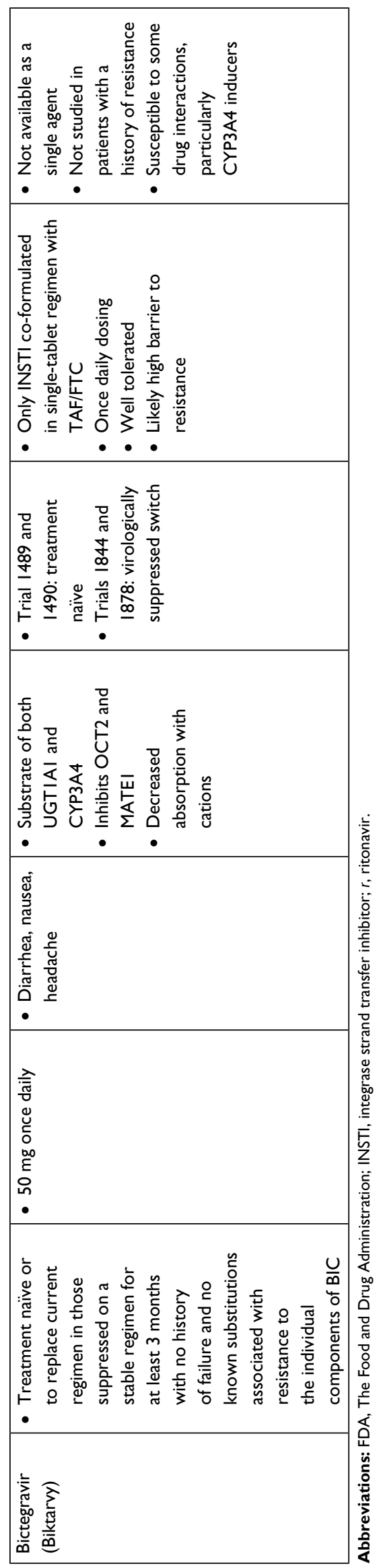

populations, unanswered questions about the use of $\mathrm{B} / \mathrm{F} /$ TAF in certain clinical situations still remain. The first being in PLWH with documented integrase resistance, or suspected integrase resistance based on virologic failure while on an integrase-based regimen. To date, this represents a relatively small population of patients; however, the use of integrase inhibitors is growing at a rapid pace and the potential for increasing class resistance (including transmitted resistance) is a real possibility. When tested against 47 patient-derived isolates with INSTI resistance mutations, BIC showed a reduced fold change as compared to wild type when compared to DTG, EVG, and RAL. Specifically BIC demonstrated $<2.5$-fold change in half maximal effective concentration in $70 \%$ of the clinical isolates vs $49 \%$ for DTG. ${ }^{30}$ However, the only clinical data that exist is the observation that one participant in a treatment-naïve study with transmitted INSTI (G140S and Q148H) and reverse transcriptase (RT) mutations (K70R and K103N) achieved viral suppression by week 4 with $\mathrm{B} / \mathrm{F} / \mathrm{TAF}$ that was maintained through week $72 .{ }^{10}$ Significantly more clinical trial data exist for the use of DTG in PLWH with documented or suspected integrase resistance. For example, in the VIKING-3 study, DTG at 50 $\mathrm{mg}$ twice daily was studied in 183 subjects who failed an RAL- or EVG-containing regimen with documented INSTI resistance. Using DTG with an optimized background, regimen resulted in $69 \%$ of subjects achieving a HIV viral load of $<50 \mathrm{c} / \mathrm{mL}$ at week $24 .^{29}$

It also remains unknown if $\mathrm{B} / \mathrm{F} / \mathrm{TAF}$ can attain and maintain viral suppression in PLWH with NRTI resistance, particularly in PLWH starting B/F/TAF with a M184V mutation that confers resistance to 3TC or FTC. In switch studies, $\mathrm{B} / \mathrm{F} / \mathrm{TAF}$ did maintain viral suppression in participants with an isolated M184V; however, these numbers were relatively small and participants were virologically suppressed at the time of exposure to $\mathrm{B} / \mathrm{F} / \mathrm{TAF} \cdot{ }^{13}$ Related to this is the question of the impact of drug interactions on the role of $\mathrm{B} / \mathrm{F} / \mathrm{TAF}$ in salvage regimens. As stated previously, BIC is a substrate of UGT1A1 but also CYP3A4. The impact of CYP3A4 inducers such as rifampin has been studied with BIC, with a significant decrease in BIC concentrations; however, BIC has not been studied with most other antiretrovirals. ${ }^{4}$ Specifically, the clinical impact of drug interactions with other antiretrovirals such as DRV in combination with ritonavir or cobicistat (which would be expected to increase BIC concentrations) or etravirine (which would be expected to decrease in BIC concentrations) remains unanswered. In addition, there are ongoing efforts to identify strategies to reduce medication exposure while maintaining viral suppression, and it is 
unclear how BIC may fit into this strategy, particularly since it is only available as a three-drug fixed dose combination.

A final unanswered question centers around the recent warning issued for DTG in which a higher prevalence of neural tube defects $(0.9 \%, 4 / 426$ patients $)$ was observed as compared to the background prevalence $(0.1 \%)$ in women in Botswana receiving DTG either during contraception or in the first trimester of pregnancy. ${ }^{32}$ This information is relatively new and still being investigated to determine if this is a true effect of the medication. DTG and BIC are similar molecules, and until more information is available, a similar concern for increased risk of neural tube defects should be considered for BIC.

\section{Conclusion}

The approval of BIC introduces the first unboosted integrase inhibitor in a fixed dose combination with TAF/FTC. The evidence for use of B/F/TAF in treatment-naïve and virologically suppressed treatment-experienced patients without resistance is strong, with the clinical trials demonstrating an equivalent rate of virologic suppression as compared to the most frequently used modern ART regimens. In addition, there was no documented resistance to BIC or any component of the STR that occurred in the clinical trials, suggesting a high barrier to resistance. Confidence in the use of BIC in treatment-experienced patients with documented or presumed resistance is yet to be established; however, it is expected that more data will accumulate over time for this specific population of PLWH.

\section{Disclosure}

MYK receives funding to the institution from Gilead Sciences and ViiV healthcare and has served on Gilead Sciences advisory board. LH has served on a ViiV advisory board. The other author reports no conflicts of interest in this work.

\section{References}

1. Zhang H, Custodio JM, Wei X, et al. Clinical pharmacology of the HIV integrase strand transfer inhibitor bictegravir. Paper presented at: The Conference on Retroviruses and Opportunistic Infections (CROI); 2017; Seattle, WA. Available from: http://www.croiconference.org/ sessions/clinical-pharmacology-hiv-integrase-strand-transfer-inhibitorbictegravir. Accessed May 29, 2018.

2. Lazerwith SE, Cai R, Chen X, et al. Discovery of GS-9883, an HIV-1 integrase strand transfer inhibitor (INSTI) with improved pharmacokinetics and in vitro resistance profile. Paper presented at: ASM Microbe; 2016; Boston, MA. Available from: http://www.natap. org/2016/HIV/062016_05.htm. Accessed May 29, 2018.

3. Tsiang M, Jones GS, Goldsmith J, et al. Antiviral activity of bictegravir (GS-9883), a novel potent HIV-1 integrase strand transfer inhibitor with an improved resistance profile. Antimicrob Agents Chemother. 2016; 60(12):7086-7097.

4. Biktarvy [package insert]. Foster City, CA: Gilead Sciences Inc.; 2018.
5. US Department of Health and Human Services. Department of Health and Human Services Adults and Adolescents Antiretroviral Guidelines Panel classifies a fixed-dose combination product of bictegravir/ tenofovir alafenamide/emtricitabine as one of the recommended initial regimens for most people with HIV. AIDSinfo. 2018. Available from: https://aidsinfo.nih.gov/news/2044/department-of-health-and-humanservices-adults-and-adolescents-antiretroviral-guidelines-panel-classifies-a-fixed-dose-combination-product-of-bictegravir-tenofovir-alafenamide-emtricitabine-as-one-of-the-recommended-initial-regimens-for. Accessed May 29, 2018.

6. Gallant JE, Thompson M, Dejesus E, et al. Antiviral activity, safety, and pharmacokinetics of bictegravir as 10-Day monotherapy in HIV1-infected adults. J Acquir Immune Defic Syndr. 2017;75(1):61-66.

7. Sax PE, Dejesus E, Crofoot G, et al. Bictegravir versus dolutegravir, each with emtricitabine and tenofovir alafenamide, for initial treatment of HIV-1 infection: a randomised, double-blind, phase 2 trial. Lancet $H I V .2017 ; 4(4): \mathrm{e} 154-\mathrm{e} 160$.

8. Gallant J, Lazzarin A, Mills A, et al. Bictegravir, emtricitabine, and tenofovir alafenamide versus dolutegravir, abacavir, and lamivudine for initial treatment of HIV-1 infection (GS-US-380-1489): a doubleblind, multicentre, phase 3, randomised controlled non-inferiority trial. Lancet. 2017;390(10107):2063-2072.

9. Sax PE, Pozniak A, Montes ML, et al. Coformulated bictegravir, emtricitabine, and tenofovir alafenamide versus dolutegravir with emtricitabine and tenofovir alafenamide, for initial treatment of HIV-1 infection (GS-US-380-1490): a randomised, double-blind, multicentre, phase 3, non-inferiority trial. Lancet. 2017;390(10107):2073-2082.

10. White K, Kulkarni R, Willkim M, et al. Pooled week 48 efficacy and baseline resistance: $\mathrm{B} / \mathrm{F} / \mathrm{TAF}$ in treatment-naive patients. Paper presented at: The Conference on Retroviruses and Opportunistic Infections (CROI); 2018; Boston, MA. Available from: http://www.croiconference. $\mathrm{org} /$ sessions/pooled-week-48-efficacy-and-baseline-resistance-bftaftreatment-naive-patients. Accessed May 29, 2018.

11. Molina JM, Ward D, Brar I, et al. Switch to bictegravir/F/TAF from DTG and ABC/3TC. Paper presented at: The Conference on Retroviruses and Opportunistic Infections (CROI); 2018; Boston, MA. Available from: http://www.natap.org/2018/CROI/croi_09.htm. Accessed May 29, 2018.

12. Daar E, Dejesus E, Ruane P, et al. Phase 3 randomized, controlled trial of switching to fixed-dose bictegravir/emtricitabine/tenofovir alafenamide $(\mathrm{B} / \mathrm{F} / \mathrm{TAF})$ from boosted protease inhibitor-regimes in virologically suppressed Adults: Week 48 results. Paper presented at: ID Week; 2017; San Diego, CA. Available from: https://idsa.confex.com/idsa/2017/ webprogram/Paper67504.html. Accessed May 29, 2018.

13. Andreatta K, Willkom M, Martin R, et al. Resistance analysis of bictegravir/emtricitabine/tenofovir alafenamide switch studies. Paper presented at: The Conference on Retroviruses and Opportunistic Infections (CROI); 2018; Boston, MA. Available from: http://www.croiconference. org/sessions/resistance-analyses-bictegraviremtricitabinetenofoviralafenamide-switch-studies. Accessed May 29, 2018.

14. Kityo C, Hagins D, Koenig E, et al. Switching to bictegravir/emtricitabine/tenofovir alafenamide in women. Paper presented at: The Conference on Retroviruses and Opportunistic Infections (CROI); 2018; Boston, MA. Available from: http://www.croiconference.org/sessions/ switching-bictegraviremtracitabinetenofovir-alafenimide-bftaf-women. Accessed May 29, 2018.

15. Gaur A, Rodriguez C, Mcgrath E, et al. Bictegravir/FTC/TAF singletablet regimen in adolescents: Week-24 results. Paper presented at: The Conference on Retroviruses and Opportunistic Infections (CROI); 2018; Boston, MA. Available from: http://www.croiconference.org/sessions/ bictegravirftctaf-single-tablet-regimen-adolescents-week-24-results. Accessed May 29, 2018.

16. Zhang H, Shao Y, Garner W, et al. The effect of hepatic or renal impairment on bictegravir pharmacokinetics. Paper presented at: The 18th International Workshop on Clinical Pharmacology of Antiviral Therapy; 2017; Chicago, IL. Available from: http://www.natap.org/2017/Pharm/ Pharm_31.htm. Accessed May 29, 2018. 
17. Custodio J, West S, Vu A, et al. Pharmacokinetics of bictegravir administered twice daily with rifampin. Paper presented at: The Conference on Retroviruses and Opportunistic Infections (CROI); 2018; Boston, MA. Available from: http://www.croiconference.org/sessions/ pharmacokinetics-bictegravir-administered-twice-daily-combinationrifampin. Accessed May 29, 2018.

18. Cerrone M, Alfarisi O, Neary M, et al. Rifampin effect on tenofovir alafenamide (TAF) plasma/intracellular pharmacokinetics. Paper presented at: The Conference on Retroviruses and Opportunistic Infections (CROI); 2018; Boston, MA. Available from: http://www. croiconference.org/sessions/rifampin-effect-tenofovir-alafenamide-tafplasmaintracellular-pharmacokinetics. Accessed May 29, 2018.

19. Zong J, Borland J, Jerva F, Wynne B, Choukour M, Song I. The effect of dolutegravir on the pharmacokinetics of metformin in healthy subjects. J Int AIDS Soc. 2014;17(4 Suppl 3):19584.

20. Custodio J, West S, Vu A, et al. Lack of clinically relevant effect of bictegravir on metformin pharmacokinetics and pharmacodynamics. Paper presented at: 18th International Workshop on Clinical Pharmacology of Antiviral Therapy; 2017; Chicago, IL. Available from: http://www.natap.org/2017/Pharm/Pharm_32.htm. Accessed May 29, 2018.

21. Eron JJ, Cooper DA, Steigbigel RT, et al. Efficacy and safety of raltegravir for treatment of HIV for 5 years in the BENCHMRK studies: final results of two randomised, placebo-controlled trials. Lancet Infect Dis. 2013;13(7):587-596.

22. Rockstroh JK, Dejesus E, Lennox JL, et al. Durable efficacy and safety of raltegravir versus efavirenz when combined with tenofovir/ emtricitabine in treatment-naive HIV-1-infected patients: final 5-year results from STARTMRK. J Acquir Immune Defic Syndr. 2013;63(1): 77-85.

23. Lennox JL, Landovitz RJ, Ribaudo HJ, et al. Efficacy and tolerability of 3 nonnucleoside reverse transcriptase inhibitor-sparing antiretroviral regimens for treatment-naive volunteers infected with HIV-1: a randomized, controlled equivalence trial. Ann Intern Med. 2014;161(7): $461-471$.
24. Sax PE, Dejesus E, Mills A, et al. Co-formulated elvitegravir, cobicistat, emtricitabine, and tenofovir versus co-formulated efavirenz, emtricitabine, and tenofovir for initial treatment of HIV-1 infection: a randomised, double-blind, phase 3 trial, analysis of results after 48 weeks. Lancet. 2012;379(9835):2439-2448.

25. Dejesus E, Rockstroh JK, Henry K, et al. Co-formulated elvitegravir, cobicistat, emtricitabine, and tenofovir disoproxil fumarate versus ritonavir-boosted atazanavir plus co-formulated emtricitabine and tenofovir disoproxil fumarate for initial treatment of HIV-1 infection: a randomised, double-blind, phase 3, non-inferiority trial. Lancet. 2012;379(9835):2429-2438

26. Walmsley SL, Antela A, Clumeck N, et al. Dolutegravir plus abacavirlamivudine for the treatment of HIV-1 infection. $N$ Engl J Med. 2013;369(19):1807-1818

27. Molina J-M, Clotet B, van Lunzen J, et al. Once-daily dolutegravir versus darunavir plus ritonavir for treatment-naive adults with HIV-1 infection (FLAMINGO): 96 week results from a randomised, open-label, phase 3b study. Lancet HIV. 2015;2(4):e127-e136.

28. Quashie PK, Mesplède T, Wainberg MA. Evolution of HIV integrase resistance mutations. Curr Opin Infect Dis. 2013;26(1):43-49.

29. Castagna A, Maggiolo F, Penco G, et al. Dolutegravir in antiretroviralexperienced patients with raltegravir- and/or elvitegravir-resistant HIV-1: 24-week results of the phase III VIKING-3 study. J Infect Dis. 2014;210(3):354-362

30. Jones G, Goldsmith J, Mulato A, et al. Bictegravir (GS-9883), a novel HIV-1 integrase strand transfer inhibitor (INSTI) with optimized in vitro resistance profile. Paper presented at: ASM Microbe; 2016; Boston, MA. Available from: http://www.natap.org/2016/HIV/062016_03.htm. Accessed May 29, 2018

31. Dolutegravir [package insert]. Research Triangle Park, NC: GlaxoSmithKline; 2013.

32. FDA. FDA Drug Safety Communication: FDA to evaluate potential risk of neural tube birth defects with HIV medicine dolutegravir (Juluca, Tivicay, Triumeq); September 2018. Available from: https://www.fda gov/Drugs/DrugSafety/ucm608112.htm. Accessed May 29, 2018.
HIV/AIDS - Research and Palliative Care

\section{Publish your work in this journal}

HIV/AIDS - Research and Palliative Care is an international, peerreviewed open access journal focusing on advances in research in HIV its clinical progression and management options including antiviral treatment, palliative care and public healthcare policies to control viral spread. The journal is included in PubMed. The manuscript man-

\section{Dovepress}

agement system is completely online and includes a very quick and fair peer-review system, which is all easy to use. Visit http://www.dovepress. com/testimonials.php to read real quotes from published authors. 